\title{
PENDOKUMENTASIAN STANDART ASUHAN KEPERAWATAN DI RUMAH SAKIT
}

\author{
ANGEL OKTAVIA PURBA / 181101099 \\ angeloktavia013@gmail.com
}

\begin{abstract}
ABSTRAK
Dokumentasi merupakan pernyataan tentang kejadian atau aktivitas yang otentik dengan membuat catatan tertulis. Dokumntasi keperawatan berisi hasil aktivitas keperawatan yang dilakukan perawat terhadap klien, mulai dari pengkajian hingga evaluasi. Tujuan dari penulisan ini adalah untuk mengetahui apa itu dokumentasi keprawatan, tujuan dilakukannya dokumnetasi keperawatan dan bagaimana pelaksanaan dokumntasian keperawatan. Metode penulisan ini adalah Literature Riview, dimana ini menganalisis artikel yang relevan dan berfokus pada tema tahap Dokumentasi keperawatan. Hasil Berdasarkan pencarian literature didapatkan apa defenisi dokumentasi keperawatan, apa tujuan dilakukannya dokumentasi dalam proses keperawatan dan bagaimana cara pelaksanaan tahap dokumentasi keperawatan.
\end{abstract}

Kata Kunci : Proses Keperawatan, Dokumentasi keperawatan, Standart Asuhan Keperawatan.

\section{LATAR BELAKANG}

Dalam asuhan keperawatan memrlukan data yang lengkap, objektif, dan dapat dipercaya. Pencapaian tujuan asuhan keperawatan yang ditempuh melalui suatu proses interaksi antar sesame anggota tim pemberi jasa dengan pengguna jasa. Oleh karena itu segala sesuatu yang menyangkut dinamika kerja yang melibatkan otoritas pemberi jasa dan pengguna jasa harus terekam dengan lengkap dan jelas demi kepentingan bersama. Kegiatan pendokumentasian keperawatan mencakup pencatatan secara sistematis terhadap semua kejadian dalam ikatan kontrak klien dalam kurun waktu tertentu secara jelas, lengkap,dan objektif. Hal ini bertujuan agar memberi kemudahan bagi perawat dalam memberikan asuhan keperawatan dan sebagai jaminan kualitas pelayanan. Disamping pencatatan, kegiatan pendokumetasian keperawatan juga mencakup penyimpanan/ pemeliharaan hasil pendokumentasian dan megkomunikasikan kepada seluruh anggota tim kesehatan untuk kepentingan pengelolaan klien serta kepada aparat penegak hukum bila diperlukan sebagai pembuktian. 


\section{TUJUAN}

Tujuan dari penulisan ini adalah untuk mengetahui apa itu dokumentasi keprawatan, tujuan dilakukannya dokumnetasi keperawatan dan bagaimana pelaksanaan dokumntasian keperawatan.

\section{METODE}

Metode penulisan ini adalah Literature Riview, dimana ini menganalisis artikel yang relevan dan berfokus pada tema tahap Dokumentasi keperawatan. Adapun sumber yang digunakan dalam literature ini menggunakan sumber dari buku teks, jurnal dengan memasukan kata kunci dokumentasi dalam proses keperawatan. Adapun jurnal yang saya yang digunakan merupakan jurnal yang diiterbitkan pada 10 tahun terakhir.

\section{HASIL}

Berdasarkan pencarian literature didapatkan apa defenisi dokumentasi keperawatan, apa tujuan dilakukannya dokumentasi dalam proses keperawatan dan bagaimana cara pelaksanaan tahap dokumentasi keperawatan.

\section{PEMBAHASAN}

Dokumentasi merupakan pernyataan tentang kejadian atau aktivitas yang otentik dengan membuat catatan tertulis. Dokumntasi keperawatan berisi hasil aktivitas keperawatan yang dilakukan perawat terhadap klien, mulai dari pengkajian hingga evaluasi. Dengan demikian, dokumentasi keperawatan ini menjadi bukti tindakan keperawatan yang dilaukan perawat terhadap klien. Karenanya, perlu dibuat sebuah format yang disepakati bersama terkait bentuk dokumentasi proses keperawatan yang berisi mulai dari pengkajian hingga evaluasi. Dokumentasi keperawatan merupakan sarana komunikas dari satu profesi lain terkait dengan status klien. Sebagai alat komunikasi, tulisan dalam dokumentasi keperawatan harus jelas terbaca, tidak boleh memakai istilah atau singkatan yang tidak lazim, juga berisi uraian yang jelas, tegas dan sistematis. Hal ini dimaksudkan untuk menghindari difungsi kkomunikasi. Lebih lanjut dampak yang ditimbulkan akibat difungsi komunikas ini akan membahayakan keselamatan pasien. Menurut Potter \& Perry (2010), dokumentasi keperawatan harus mencantumkan seluruh proses asuhan 
keperawatan, mulai dari pengkajian dengan menetapkan data dasar seorang klien , diagnosa keperawatan untuk mengidentifikasi permasalahan yang dihadapi pasien, intervensi yaitu merencanakan asuhan keperawatan kepada pasien, implementasi yaitu serangkaian kegiatan yang dilakukan oleh perawat untuk membantu klien dari masalah status kesehatan yang dihadapi kestatus kesehatan yang lebih baik yang menggambarkan kriteria hasil yang diharapkan dan evaluasi merupakan perbandingan yang sistematik dan terencana tentang kesehatan klien dengan tujuan yang telah ditetapkan, dilakukan berkesinambungan dengan melibatkan klien dan tenaga kesehatan lainnya. Pengisian dokumentasi keperawatan yang tidak sesuai dengan standar dapat menyebabkan perbedaan tindakan oleh perawat lain sehingga menyebabkan terjadinya penurunan kualitas pelayanan.

Tujuan utama dilakukannya dokumentasi adalah untuk : 1) Mengidentifikasi status kesehatan klien dalam rangka mendokumentasikan kebutuhan klien, merencanakan, melaksanakan asuhan keperawatan dan mengevaluasi intervensi. keuangan, hukum, dan etika. Hal ini juga menyediakan :

- Bukti kualitas asuhan keperawatan.

- Bukti legal dokumnetasi sebagai petanggungjawaban kepada klien.

- Informasi terhadap perlindungan individu.

- Sumber informasi statistika untuk standart dan riset keperawatan.

- Penguurangan biaya informasi.

- Sumber informasi untuk data yang harus dimasukkan.

- Komunikasi konsep resiko asuhan keperawatn.

- Persepsi hak klien.

- Dokumentasi untuk tenaga profesional, tanggung jawab etik, dan menjaga kerahasiaan informasi klien.

- Suatu data keungan yang sesuai.

- Data perencanaan pelayanan kesehatan dimmasa yang akan datang.

Dokumentasi juga mempunyai manfaat dan mempunyai makna yang penting dilihat dari berbagai aspek seperti aspek hukum, kualitas pelayanan, komunikasi,
2) Dokumentas
untuk
penilaian, 
keuangan, pendidikan, penelitian, dan akreditasi.

Pendokumentasian keperawatan merupakan metode yang tepat untuk pengambilan keputusan tang sistematis, Problem-solving, dan riset lebih lanjut. Untuk pendokumentasian yang efektif maka perawat harus melakukan langkah-langkah sebagai berikut :

(1)Menggunakan standart terminology (pengkajian, diagnosis, perencanaan, implementasi, dan evaluasi ). (2)Mengumpulkan dan mendokumentasikan data yang bermanfaat dan relevan sesuai dengann prosedur dalam catatan yang parmanen. (3)Menegakkan diagnosis keperawatan berdasarkan klasifikaso dan analisis data yang akurat. (4)Menulis dan mendokumentasikan rencana asuhan keperawatan sebagai bagian dari catatan yang permanent. (5)Mendokumentasikan hasil observasi secara akurat, lengkap, dan sesuai urutan waktu. (6)Mendokumentasikan evaluasi sesuai urutan waktunya yang meliputi selama dirawat, dirijuk pulang ataupun perubahan keadaan klien. Respond klien terhadap intervensi keperawatan dan medis juga perlu dituliskan.
(7)Merevisi rencana asuhan keperawatan berdasarkan hasil yang diharapkan pada klien.

Perawa memerlukan suatu keterampilan untuk memenuhi Standar yang sesua dalam pendokumentasian. Standart disini maksudnya adalah suatu ukuran atau model yang harus dipenuhi oleh hala-hal yang serupa. Standart asuhan keperawatan adalah pernyataan tentang kualitas dan kuantitas dokumentasi yang dipertimbangkan dengan baik dalam suatu situasi tertentu. Contoh penggunaan pola standart dokumentasi yang efektif : 1) Kepatuhan terhadap aturan pendokumentasian yang ditetapkan oleh profesi atau pemerintah. 2) Standart profesi keperwatan dituliskan ke dalam catatan kesehatan. 3) Peraturan tentang prakti keperawatan dapat dilihat pada catatan pelayanan kesehatan. 4) Pedoman akreditasi harus diikuti.

\section{KESIMPULAN}

Dokumentasi merupakan pernyataan tentang kejadian atau aktivitas yang otentik dengan membuat catatan tertulis. Dokumntasi keperawatan berisi hasil aktivitas keperawatan yang dilakukan perawat terhadap klien, mulai dari pengkajian hingga evaluasi. 
Tujuan utama dilakukannya dokumentasi adalah untuk : Mengidentifikasi status kesehatan klien dalam rangka mendokumentasikan kebutuhan klien, merencanakan, melaksanakan asuhan keperawatan dan mengevaluasi intervensi dan Dokumentasi untuk penilaian, keuangan, hukum, dan etika. Perawat memerlukan keterampilan dalam mendokumentasikan proses keperawatan. Pendokumentasian keperawatan merupakan metode yang tepat untuk pengambilan keputusan tang sistematis, Problem-solving, dan riset lebih lanjut.

\section{SARAN}

.Salah satu upaya untuk meningkatkan kualitas pelayanan adalah dengan melaksanakan standar dokumentasi keperawatan sehingga pelayanan keperawatan pada pasien yang sakit dapat dilaksanakan secara berkelanjutan dan efisiensi waktu dapat dicapai.

\section{DAFTAR PUSTAKA}

Allen, C. V. (1998). Memahami Proses Keperawatan. Jakarta. EGC.

Asmadi. (2008). Konsep Dasar Keperawatan. Jakarta. EGC.

Budiono \& Sumirah,B,P.(2016). Konsep Dasar Keperawatan (Ed 2). Jakarta. Bumi Medika.

Dermawan, Deden. (2012). Proses Keperawatan : Penerapan Konsep Dan Kerangka Kerja. Yogyakarta : Gosyen Publishing.

Handayaningsih, I. (2009). Dokumentasi Keperawatan “DAR”. Jogjakarta. Mitra Cendekia.

Nursalam. (2008). Proses dan Dokumentasi Keperawatan ed 2. Jakarta. Salemba Medika.

Nursalam. (2001). Proses \& Dokumentasi Keperawatan Konsep dan Praktik. Jakarta. Salemba Medika

Haryanto. (2007). Konsep Dasar Keperawatan Dengan Peemetaan Konsep. Jakarta : Salemba Medika. 
Hidayat, A. Aziz Alimut. (2004). Tarwoto \& Wartonah. (2012).

Pengantar Konsep Dasar Kebutuhan Dasar Manusia Dan Proses

Kepperawatan. Jakarta. Salemba Keperawatan. Jakarta : Salemba Medika.

Medika.

Lismidar,H.(1990).Proses

Keperawatan. Jakarta : Universitas

Indonesi.

Potter \& Perry. (2005). Buku Ajar

Fundamental Keperawatan Konsep

Proses Dan Praktik Edisi 4. Jakarta :

EGC.

Potter \& Perry. ( 2010). Fundamental

Of Nursing : Edisi 7. Jakarta : EGC.

Rohma, N \& Wahid, S. (2009). Proses

Keperawattan. Arruz Media.

Simamora, R. H. (2009). Dokumentasi

keperawatan. Jamber University Press.

Simamora, R. H. ( 2010). Komunikasi

Dalam Keperawatan. Jamber

University Press.

Simamora, R. H. (2008). Peran Manajemen Pembinaan Etika Perawat Pelaksanan Dalam Peningkatan Kualitas Pelayanan Asuhan Keperawatan. Jurnal IKESMA. 